\title{
The role of the transdiaphragmatic pressure gradient in the pathophysiology of gastroesophageal reflux disease
}

\author{
Leonardo M DEL GRANDE¹, Fernando A M HERBELLA', Rafael C KATAYAMA', \\ Francisco SCHLOTTMANN ${ }^{2}$ and Marco G PATTI ${ }^{2}$
}

Received 22/1/2018 Accepted 29/1/2018

\begin{abstract}
Gastroesophageal reflux disease (GERD) is the most common disease of the upper gastrointestinal tract in the Western world. GERD pathophysiology is multifactorial. Different mechanisms may contribute to GERD including an increase in the transdiaphragmatic pressure gradient (TPG). The pathophysiology of GERD linked to TPG is not entirely understood. This review shows that TPG is an important contributor to GERD even when an intact esophagogastric barrier is present in the setting of obesity and pulmonary diseases.
\end{abstract}

HEADINGS - Gastroesophageal reflux disease. Pressure. Lower esophageal sphincter. Obesity. Respiratory tract diseases.

\section{INTRODUCTION}

Gastroesophageal reflux disease (GERD) is a common disease in the Western world with a raising prevalence in the last decades. It is currently the most common chronic disorder of the upper digestive $\operatorname{tract}^{(1)}$ and it is estimated that GERD affects 10\%-20\% of the population ${ }^{(2)}$. In the US, GERD symptoms are felt at least weekly by $10 \%-25 \%$ of the population ${ }^{(3,4)}$.

GERD pathophysiology is multifactorial with different factors contributing to its genesis. A defective esophagogastric barrier is commonly found in patients with GERD, since $75 \%$ of the individuals have a hypotonic lower esophageal sphincter (LES) ${ }^{(5)}$. A quarter of the individuals; however, have normal LES pressure and length. Some studies showed that transient LES relaxation (TLESR) may be the cause for GERD in these patients ${ }^{(1,5,6)}$. Others believe on the role of esophageal body dysmotility that leads to a faulty esophageal clearance exacerbating mucosal damage and allowing reflux to reach higher levels ${ }^{(6)}$ or on the defective action of the diaphragm as an extrinsic sphincter in the absence of hiatal hernia $(\mathrm{HH})^{(7)}$. Other possible factors are still the composition of the refluxate, mucosal integrity, visceral sensitivity, esophagogastric diminished compliance, and delayed gastric emptying ${ }^{(1,5)}$.

Transdiaphragmatic pressure gradient (TPG) is part of GERD pathophysiology as well. The difference in pressure between positive gastric/abdominal pressure (AP) and the negative esophageal/thoracic pressure (TP) may exceed the pressure of the esophagogastric barrier represented by the LES and the diaphragm. This gradient may account for GERD ${ }^{(8)}$. Some groups of patients - such as those with lung diseases ${ }^{(9)}$ or obesity ${ }^{(10)}$ - have a higher risk of developing an elevated TPG and, not surprisingly, are at higher risk to have GERD. The mechanism is a raise in AP in the case of obesity ${ }^{(11)}$ and a decrease in TP in chronic pulmonary disorders ${ }^{(12)}$.
This review focuses on the role of TPG on GERD pathophysiology.

\section{Transdiaphragmatic pressure gradient quantification by esophageal manometry}

AP and TP are parameters not routinely measured during esophageal manometry. At the time of conventional manometry, only few studies ${ }^{(13-15)}$ tried to measure TPG in GERD patients comparing inspiratory, mean respiratory or both pressures with variable methodology and without establishing reference values for normal individuals ${ }^{(13-15)}$. This is related to several limitations faced by conventional manometry, such as: (a) catheter movement artifacts that may include LES pressure with gastric or thoracic pressures if measurements are taken close to the sphincter; (b) inability to identify altered respiratory movements such as thoracic pressurization during moments of stress; (c) different parameters for zeroing baseline if different channels are used to measure thoracic or abdominal pressure; and (d) inability to identify gastric contractions that may be included during abdominal pressure recording ${ }^{(16)}$.

High resolution manometry eliminates some of these limitations and recently some studies are focused on TPG at the light of this technology ${ }^{(16-20)}$. There is not; however, a standardization of methodology yet. Our preference is to calculate TPG subtracting the thoracic pressure measured at $2 \mathrm{~cm}$ above the upper border of the LES considering its respiratory excursion and the abdominal pressure at $2 \mathrm{~cm}$ below the lower border of the LES also considering its respiratory excursion. Both pressures are calculated based on the average pressure in a $30 \mathrm{~s}$ period encompassing all phases of the respiration (mid-respiratory measurement) ${ }^{(17)}$ (FIGURE 1). We also measure LES retention pressure as defined by LES midrespiratory basal pressure minus TPG.

Declared conflict of interest of all authors: none

Disclosure of funding: no funding received

'Universidade Federal de São Paulo, Escola Paulista de Medicina, Departamento de Cirurgia, São Paulo, SP, Brasil. ${ }^{2}$ University of North Carolina, Department of Medicine and Surgery, Chapel Hill, North Carolina, USA.

Corresponding author: Fernando Herbella. Orcid: 0000-0003-3594-5744. E-mail: herbella.dcir@epm.br 


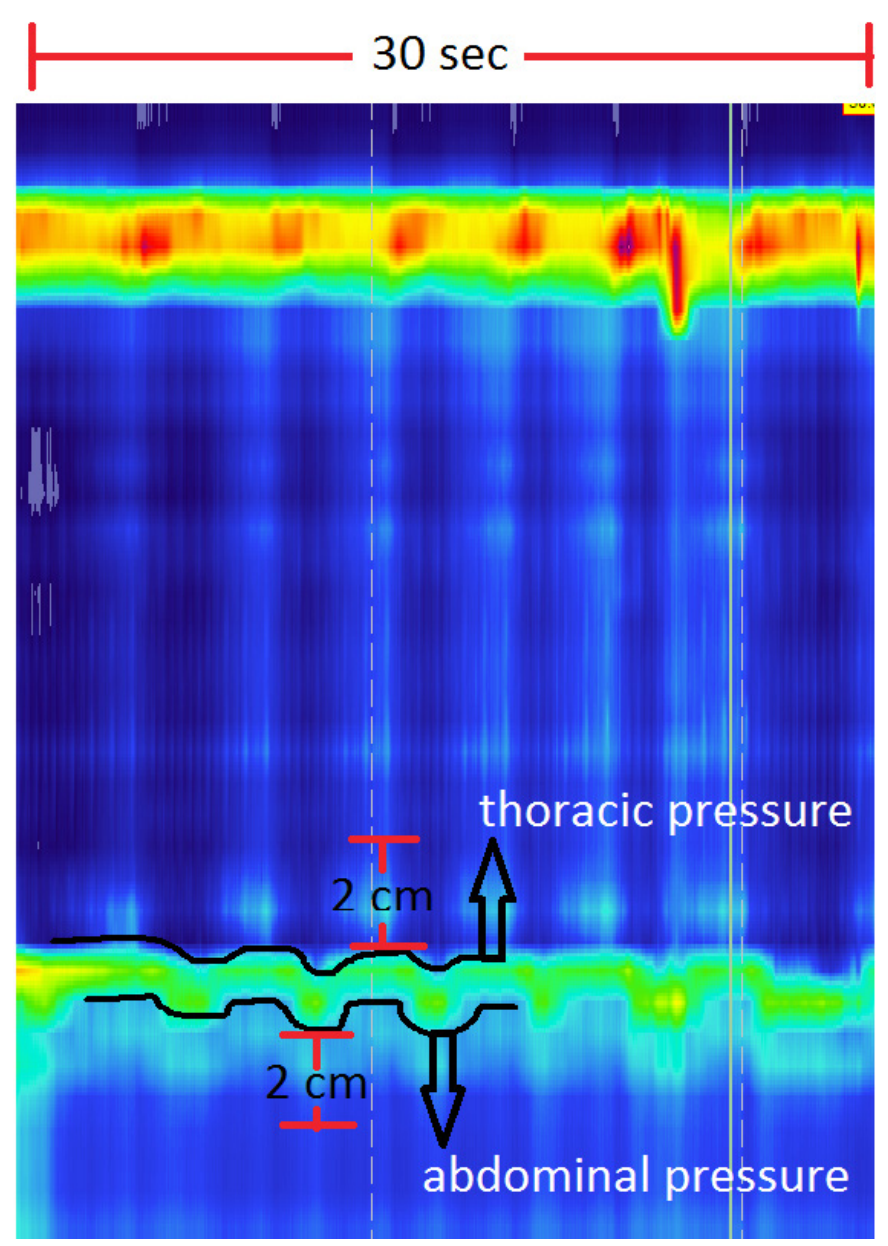

FIGURE 1. Measurement of the abdominal and thoracic pressures to calculate the transdiaphragmatic pressure gradient with the aid of the high resolution manometry.

\section{Transdiaphragmatic pressure gradient in health}

There is no reference values originated from healthy volunteers available. We use the parameters obtained from 32 healthy volunteers studied in our laboratory $(n=32$, mean age $33.1 \pm 8.7,70 \%$ females). The results are expressed in TABLE 1.
Some physiologic conditions may influence TPG, such as exercise. Physical activity may alter TPG due to changes in both AP and $\mathrm{TP}^{(20)}$. Also, the number of TLESR seems to increase during exercise ${ }^{(21)}$. During the postprandial period, and increase in AP and TPG may be noticed ${ }^{(22)}$.

\section{Transdiaphragmatic pressure gradient and gastroesophageal reflux disease}

The role of TPG on GERD pathophysiology is not well understood. Apart from altered AP and TP, TPG may be also influenced by compliance of the distal esophagus, changes in diaphragmatic morphology ${ }^{(13,23-25)}$. The important role of TPG must be; however, associated to TLESR, obesity, hiatal hernia and pulmonary diseases.

\section{- Transient lower esophageal sphincter relaxation and} the transdiaphragmatic pressure gradient

TLESR is a physiologic phenomenon secondary to gastric distension, defined by LES relaxation occurring in absence of swallowing, lasting more than 10 seconds, and associated with crural inhibition $^{(26)}$. GERD patients have two times more episodes of reflux during TLESR as compared to normal individuals ${ }^{(27)}$. A possible explanation for an increase in the episodes of reflux is an increase in the TPG in these patients ${ }^{(8,18,22-23,25,27-30)}$ that occurs shortly before TLESR ${ }^{(31)}$. This may explain GERD in the setting of a normotonic $\operatorname{LES}^{(5,32)}$.

\section{- Obesity and transdiaphragmatic pressure gradient}

Obesity increases the risk for GERD ${ }^{(11,33)}$. Different studies showed that increase in weight is linked to a higher prevalence of GERD ${ }^{(10,11,34-36)}$. Moreover, obese individuals have more symptoms $^{(35,36)}$, increased esophageal acid exposure ${ }^{(37)}$, higher incidence of Barrett's esophagus ${ }^{(38)}$, and $\mathrm{HH}^{(11,39)}$ as compared to lean individuals. Although TPG is intuitively considered part of GERD pathophysiology in obese individuals, this condition has been poorly studied objectively. Increased AP (and consequent increased TPG) found in the obese favors GERD ${ }^{(14,39)}$. Increased waist circumference and body mass index are associated to a raise in $\mathrm{TPG}^{(14,17,40)}$. For each 1-point increase in body mass index, AP is expected to increase $10 \%{ }^{(41)}$. Few studies however, were able to demonstrate a direct link between AP and esophageal acid exposure in the obese ${ }^{(14,42)}$.

Obesity may affect not only $\mathrm{AP}^{(11)}$. Diaphragm elevation due to intraabdominal visceral obesity can lead to respiratory restriction, and consequent higher effort in the respiratory drive with a consequent decrease in the $\mathrm{TP}^{(43)}$. Moreover, sleep apnea is highly prevalent in the obese population ${ }^{(44)}$ and affects TP as well ${ }^{(45)}$.

TABLE 1. Transdiaphragmatic pressure gradient in healthy individuals.

\begin{tabular}{|c|c|c|c|c|}
\hline Manometric parameter & Method & $\begin{array}{c}\text { Average } \\
\pm \text { Standard deviation }\end{array}$ & $\begin{array}{c}\text { Median } \\
\text { (interquartile 25-75) }\end{array}$ & Range \\
\hline Abdominal pressure $(\mathrm{mmHg})$ & $2 \mathrm{~cm}$ bellow lower border LES & $11.6 \pm 4.5$ & $11.4(7.8-15.1)$ & $2.6-19.6$ \\
\hline Thoracic pressure $(\mathrm{mmHg})$ & $2 \mathrm{~cm}$ above upper border LES & $7.4 \pm 5.4$ & $7.4(4.2-8.8)$ & $-3.7-18.4$ \\
\hline Transdiaphragmatic pressure gradient & $\begin{array}{l}\text { Abdominal pressure } \\
\text { Thoracic pressure }\end{array}$ & $4.5 \pm 2.9$ & $4.4(2.0-7.1)$ & $-0.2-10.6$ \\
\hline LES retention pressure $(\mathrm{mmHg})$ & $\begin{array}{c}\text { LES basal pressure } \\
\text { Transdiaphragmatic pressure } \\
\text { gradient }\end{array}$ & $16.5 \pm 12.1$ & $13.3(6.6-28.9)$ & $-1-39.7$ \\
\hline
\end{tabular}

LES: lower esophageal sphincter. 


\section{- Hiatal hernia and transdiaphragmatic pressure gradient}

$\mathrm{HH}$ is an independent risk factor for GERD ${ }^{(5)}$. HH leads to a morphologic alteration at the esophagogastric junction leading to the loss of some natural antireflux mechanisms and decreasing LES pressure $^{(23,24,46)}$. TPG may also be increased due to pressurization of the herniated supra-diaphragmatic gastric pouch and a decrease of the esophageal compliance ${ }^{(14,47)}$.

On the other side, an increased TPG may increase the chance of a HH. Pandolfino et al. ${ }^{(19)}$ demonstrated that spatial separation of the LES and the diaphragm at the high resolution manometry is higher in overweight and obese individuals with increased TPG (due to an increased AP). Also, there is a high incidence of $\mathrm{HH}$ in patients with pulmonary interstitial fibrosis probably due to a decreased $\mathrm{TP}^{(48)}$.

TPG may challenge the hiatal repair performed during an antireflux operation and affect $\mathrm{HH}$ recurrence. $\mathrm{HH}$ recurrence seems to be higher in the obese ${ }^{(11)}$. In the chronic pulmonary diseases population, although antireflux operations are currently performed even in end-stage transplant-list patients, late results and the real $\mathrm{HH}$ recurrence rate are elusive in the literature.

\section{- Pulmonary diseases and transdiaphragmatic pressure gradient}

The association of GERD and pulmonary disease is a frequent one and certainly a causality association not a spurious relation. Several recent studies showed an increased prevalence of GERD in patients with asthma, pulmonary fibrosis, chronic cough and chronic obstructive pulmonary disease $(\mathrm{COPD})^{(12,17,49-52)}$. GERD may damage the lung due to aspiration of gastric contents but pulmonary diseases may cause GERD due to changes in the TPG. The increased respiratory effort common in certain lung disorders may alter TP. This was clearly demonstrated in patients with COPD and GERD ${ }^{(17)}$. This group of patients has a lower TP compared to patients with COPD but without GERD, even though LES pressure is similar for both ${ }^{(17)}$. Interestingly, TP is significantly increased after bronchodilators are inhaled ${ }^{(52)}$. In other lung disorders, such as interstitial fibrosis; however, an intrinsic failure of the LES is the most common finding ${ }^{(53,54)}$.

\section{Transdiaphragmatic pressure gradient - therapeutic applications}

GERD has a complex pathophysiology with many factors contributing to the ascent of gastric contents to the esophagus. However, in summary, GERD occurs as a result of failure of the esophagogastric barrier, either due to an intrinsic defect of the valve apparatus or its retention capacity subdued by an altered $\mathrm{TPG}^{(55)}$. GERD control, in patients in whom TPG may play an important role, may be thus aimed towards the esophagogastric barrier or normalization of TPG.

\section{- Non-obese, non-pulmonary patients}

Laparoscopic fundoplication is very effective in controlling GERD $^{(56,57)}$. This technique not only restores the competence of the esophagogastric barrier by improving LES pressure ${ }^{(58)}$ but also decreases the number of TLESR ${ }^{(5,60)}$. Scheffer et al. showed that TPG is higher when an episode of reflux is associated to a TLESR and that a fundoplication decreases TPG during TLESR ${ }^{(8)}$. Moreover, a fundoplication improves esophageal body contractility ${ }^{(58)}$. This action may influence distal esophageal compliance raising $\mathrm{TP}^{(17)}$.

\section{- Obese patients}

Weight loss leads to a reduction in AP. This is translated in a decrease in GERD symptoms ${ }^{(61)}$ and $\mathrm{pH}$ monitoring parameters $^{(22,63)}$.

Fundoplication in the obese is a controversial topic ${ }^{(10)}$. While it does not act in the major component of GERD pathophysiology, i.e., TPG, it is a simple and efficient procedure with good outcomes even in the obese ${ }^{(64-66)}$. However, there are data showing a higher rate of complications, technical difficulty and worse results ${ }^{(67,68)}$. A recent tendency is to offer a bariatric operation to these patients ${ }^{(69-71)}$.

Some bariatric procedures - such as gastric band and sleeve gastrectomy - lead to a decrease in visceral adiposity and consequent lower AP but may have controversial results in regards to intra-gastric pressure. While some believe there is a raise in intragastric pressure due to flow restriction ${ }^{(72)}$, others support that gastric emptying is accelerated ${ }^{(73)}$. Studies focused on the development or amelioration of GERD after these restrictive procedures are still very controversial ${ }^{(10,11,72-78)}$.

Roux-en-Y gastric bypass on the other hand is considered an excellent treatment for GERD in the obese ${ }^{(71)}$. Several series show improvement in symptoms ${ }^{(79,80)}$, acid exposure ${ }^{(81)}$ and extraesophageal manifestations ${ }^{(82)}$. Weight loss summed to maintenance of esophageal ${ }^{(83)}$ and rapid gastric emptying ${ }^{(84)}$ favorably act on favor of decreasing TPG and GERD control that is added to a decrease in the population of acid-producing parietal cells and bile diversion.

\section{- Pulmonary patients}

GERD plays an important role in the pathogenesis of pulmonary diseases ${ }^{(85)}$, and efforts must be made to accurately diagnose it and properly treat $\mathrm{it}^{(9)}$. A laparoscopic fundoplication does not act directly in the pulmonary mechanics to improve TPG but it controls GERD. Asthma exacerbations and medication usage are decrease after GERD treatment ${ }^{(86-88)}$. Idiopathic fibrosis is also improved by GERD control ${ }^{(89)}$. Better respiratory parameters are achieved in COPD patients after antireflux surgery that may affect TP towards normalization ${ }^{(90,91)}$.

\section{CONCLUSION}

GERD has a multifactorial and complex pathophysiology. TPG may be an important contributor to GERD even with an intact esophagogastric barrier during TLESR and in the setting of obesity and pulmonary diseases. The current literature on the topic is still faulty. Clear conclusions on the influence of TPG in GERD pathophysiology are currently not possible but plausible theories may be drawn based on data extrapolation.

\section{Authors' contribution}

Del Grande LM: acquisition of data, drafting the article, analysis and interpretation of data, final approval of the version to be published. Herbella FAM: conception and design, acquisition of data, analysis and interpretation of data, drafting the article, final approval of the version to be published. Katayama RC: acquisition of data, final approval of the version to be published. Schlottmann F: review for intellectual content, final approval of the version to be published. Patti MG: conception and design, analysis and interpretation of data, review for intellectual content, final approval of the version to be published. 
Del Grande LM, Herbella FAM, Katayama RC, Schlottmann F, Patti MG. O papel do gradiente pressórico transdiafragmático na fisiopatologia da doença do refluxo gastroesofágico. Arq Gastroenterol.

RESUMO - A doença do refluxo gastroesofágico (DRGE) é a enfermidade mais comum do trato digestivo alto no mundo ocidental. A fisiopatologia da DRGE é multifatorial. Diferentes mecanismos podem contribuir para um aumento do gradiente pressórico transdiafragmático (GPT). A fisiopatologia da DRGE associada ao GPT não é totalmente compreendida. Esta revisão enfoca que o GPT é um importante contribuinte para DRGE mesmo na presença de uma barreira gastroesofágica intacta como na obesidade e doenças pulmonares crônicas.

DESCRITORES - Refluxo Gastroesofágico. Pressão. Esfíncter esofágico inferior. Doenças respiratórias.

\section{REFERENCES}

1. Herregods TV, Bredenoord AJ, Smout AJ. Pathophysiology of gastroesophageal reflux disease: new understanding in a new era. Neurogastroenterol Motil. 2015;27:1202-1213

2. Katz P, Gerson LB, Vela MF. Guidelines for the diagnosis and management of gastroesophageal reflux disease. Am J Gastroenterol. 2013;108:308-328; quiz 329

3. Hummel K, Richards W. Endoscopic treatment of gastroesophageal reflux disease. Surg Clin North Am. 2015;95:653-67.

4. Moraes-Filho JP, Chinzon D, Eisig JN, Hashimoto CL, Zaterka S. Prevalence of heartburn and gastroesophageal reflux disease in the urban Brazilian population. Arq Gastroenterol. 2005;42:122-7.

5. Herbella FA, Patti MG. Gastroesophageal reflux disease: From pathophysiology to treatment. World J Gastroenterol. 2010;16:3745-9.

6. Patti MG, Diener URS, Tamburini A, Molena D, Way LW. Role of esophageal function testes in diagnosis of gastroesophageal reflux disease. Dig Dis Sciences. 2001;4:597-602.

7. Pandolfino JE, Kim H, Ghosh SK, Clarke JO, Zhang Q, Kahrilas PJ. High-resolution manometry of the EGJ: an analysis of crural diaphragm function in GERD. Am J Gastroenterol. 2007;102:1056-63.

8. Scheffer RC, Gooszen HG, Hebbard GS, Samsom M. The role of transsphincteric pressure and proximal gastric volume in acid reflux before and after fundoplication. Gastroenterology. 2005;129:1900-9.

9. Lee AL, Goldstein RS. Gastroesophageal reflux disease in COPD: links and risks. Int J Chron Obstruct Pulmon Dis. 2015;10:1935-49.

10. Khan A, Kim A, Sanossian C, Francois F. Impact of obesity treatment on gastroesophageal reflux disease. World J Gastroenterol. 2016;22940:1627-38.

11. Nadaleto BF, Herbella FA, Patti MG. Gastroesophageal reflux disease in the obese: Pathophysiology and treatment. Surgery. 2016;159:475-86.

12. Casanova C, Baudet JS, del Valle Velasco M, Martin JM, Aguirre-Jaime A, de Torres JP, Celli BR. Increased gastro-oesophageal reflux disease in patients with severe COPD. Eur Respir J. 2004;23:841-5.

13. Ayazi S, DeMeester SR, Hsieh CC, Zehetner J, Sharma G, Grant KS, et al. Thoraco-abdominal pressure gradients during the phases of respiration contribute to gastroesophageal reflux disease. Dig Dis Sci. 2011;56:1718-22.

14. de Vries DR, van Herwaarden MA, Smout AJ, Samsom M. Gastroesophageal pressure gradients in gastroesophageal reflux disease: relations with hiata hernia, body mass index, and esophageal acid exposure. Am J Gastroenterol. 2008; 103:1349-54

15. Fornari F, Fucilini LM, Risson C, Rossi L, Gelain A, Barros SG. Contribution of standard oesophageal manometry in sliding hiatal hernia: from the gastro-oesophageal pressure gradient to the diagnosis. Dig Liver Dis. 2009;41:886-90.

16. Herbella FA, Aprile LR, Patti MG. High-resolution manometry for the evaluation of gastric motility. Updates Surg. 2014:66:177-81.

17. Del Grande LM, Herbella FA, Bigatao AM, Abrao H, Jardim JR, Patti MG Pathophysiology of Gastroesophageal Reflux in Patients with Chronic Pulmonary Obstructive Disease Is Linked to an Increased Transdiaphragmatic Pressure Gradient and not to a Defective Esophagogastric Barrier. J Gastrointest Surg. 2016;20:104-10

18. Ribolsi M, Balestrieri, R. Holloway H, Emerenziani S, Cicala M. Intra-bolus pressure and esophagogastric gradient, assessed with high-resolution manometry, are associated with acid exposure and proximal migration of refluxate. Dis Esophagus. 2016;29:1020-6.

19. Pandolfino JE, El-Serag HB, Zhang Q, Shah N, Ghosh SK, Kahrilas PJ. Obesity: a challenge to esophagogastric junction integrity. Gastroenterology. 2006;130:639-49.

20. Maddison KJ, Shepherd KL, Hillman DR, Eastwood PR. Function of the lower esophageal sphincter during and after high-intensity exercise. Med Sci Sports Exerc. 2005;37:1728-33.

21. Herregods TV, van Hoeij FB, Oors JM, Bredenoord AJ, Smout AJ. Effect of Running on Gastroesophageal Reflux and Reflux Mechanisms. Am J Gastroenterol. 2016. doi: 10.1038/ajg.2016.122.
22. Frankhuisen R, Van Herwaarden MA, Scheffer RCh, Hebbard GS, Gooszen $\mathrm{HG}$, Samsom M. Increased intragastric pressure gradients are involved in the occurrence of acid reflux in gastroesophageal reflux disease. Scand J Gastroenterol. 2009;44:545-50.

23. Kahrilas PJ, Shi G, Manka M, Joehl RJ. Increased frequency of transient lower esophageal sphincter relaxation induced by gastric distention in reflux patients with hiatal hernia. Gastroenterology 2000;118:688-95.

24. Tipnis NA, Rhee PL, Mittal RK. Distension during gastroesophageal reflux effects of acid inhibition and correlation with symptoms. Am J Physiol Gastrointest Liver Physiol. 2007;293:469-74.

25. Pandolfino J E, Shi G, Trueworthy B, Kahrilas PJ. Esophagogastric junction opening during relaxation distinguishes nonhernia reflux patients, hernia patients, and normal subjects. Gastroenterology. 2003;125:1018-24

26. Roman S, Holloway R, Keller J, Herbella F, Zerbib F, Xiao Y, et al. Validation of criteria for the definition of transient lower esophageal sphincter relaxations using high-resolution manometry. Neurogastroenterol Motil. 2017;29(2). doi: $10.1111 / \mathrm{nmo}$.

27. Hershcovici T, Mashimo H, Fass R. The lower esophageal sphincter. Neurogastroenterol Motil. 2011;23:819-30.

28. Van Herwaarden MA, Samsom M, Smout AJ. Excess gastroesophageal reflux in patients with hiatus hernia is caused by mechanisms other than transient LES relaxations. Gastroenterology. 2000;119:1439-46.

29. Bredenoord AJ, Weusten BL, Timmer R, Smout AJ. Intermittent spatial separation of diaphragm and lower esophagealsphincter favors acidic and weakly acidic reflux. Gastroenterology. 2006;130:334-40.

30. Pandolfino JE, Zhang QG, Ghosh SK, Han A, Boniquit C, Kahrilas PJ. Transient lower esophageal sphincter relaxations and reflux: mechanistic analysis using concurrent fluoroscopy and high-resolution manometry. Gastroenterology. 2006; $131: 1725-33$.

31. Sifrim D, Tack J, Lerut T, Janssens J Transient lower esophageal sphincter relaxations and esophageal body muscular contractile response in reflux esophagitis. Dig Dis Sci. 2000;45:1293-300.

32. Benati CD, Herbella FA, Patti MG. Manometric parameters in patients with suspected Gastroesophageal reflux disease and normal $\mathrm{pH}$ monitoring. GED Gastroenterol Endosc Dig. 2014;33:52-7.

33. Friedenberg FK, Xanthopoulos M, Foster GD, Richter JE. The association between gastroesophageal reflux disease and obesity. Am J Gastroenterol. 2008;103:2111-22.

34. Anand G, Katz PO. Gastroesophageal reflux disease and obesity. Gastroenterol Clin North Am. 2010;39:39-46.

35. Locke GR III, Talley NJ, Fett SL, Zinsmeister AR, Melton LJ III. Risk factors associated with symptoms of gastroesophageal reflux. Am J Med. 1999;106:642-9.

36. Nilsson M, Johnsen R, Ye W, Hveem K, Lagergren J. Obesity and estrogen as risk factors for gastroesophageal reflux symptoms. JAMA. 2003;290:66-7.

37. El-Serag HB, Ergun GA, Pandolfino J, , Fitzgerald S, Tran T, Kramer JR. Obesity increases oesophageal acid exposure. Gut. 2007;56:749-55.

38. Kindel TL, Oleynikov D. The improvement of Gastroesophageal Reflux Disease and Barrett's after Bariatric Surgery. Obes Surg. 2016;26:718-20.

39. Wilson LJ, Ma W, Hirschowitz BI. Association of obesity with hiatal hernia and esophagitis. Am J Gastroenterol. 1999;94:2840-4

40. Pandolfino JE. The relationship between obesity and GERD: "big or overblown". Am J Gastroenterol. 2008;103:1355-7.

41. El-Serag HB, Tran T, Richardson P, Ergun G. Anthropometric correlates of intragastric pressure. Scand J Gastroenterol. 2006:41:887-91.

42. Fornari F, Madalosso CA, Farré R, Gurski RR, Thiesen V, Callegari-Jacques $\mathrm{SM}$. The role of gastro-oesophageal pressure gradient and sliding hiatal hernia on pathological gastro-oesophageal reflux in severely obese patients. Eur J Gastroenterol Hepatol. 2010;22:404-11.

43. Steier J, Lunt A, Hart N, Polkey MI, Moxham. Observational study of the effect of obesity on lung volumes. Thorax. 2014;69:752-9. 
44. Frey WC, Pilcher J. Obstructive sleep-related breathing disorders in patients evaluated for bariatric surgery. Obes Surg. 2003;13:676-83.

45. Marcus JA, Pothineni A, Marcus CZ, Bisognano JD. The role of obesity and obstructive sleep apnea in the pathogenesis and treatment of resistant hypertension. Curr Hypertens Rep. 2014;16:411.

46. Fein M, Ritter MP, DeMeester TR, Oberg S, Peters JH, Hagen JA, Bremner CG. Role of the lower esophageal sphincter and hiatal hernia in the pathogenesis of gastroesophageal reflux disease. J Gastrointest Surg. 1999;3:405-10.

47. Smith ABD, Dickerman RDD, McGuire CSD, East JW, McConathy WJ, Pearson HF. Pressure-overload-induced sliding hiatal hernia in power athletes. J Clin Gastroenterol. 1999;28:352-4.

48. Harding SM. Recent clinical investigations examining the association of asthma and gastroesophageal reflux. Am J Med. 2003;115 Suppl 3A:39S-44S

49. Tossier C, Dupin C, Plantier L, Leger J, Flament T, Favelle O, et al. Hiatal hernia on thoracic computed tomography in pulmonary fibrosis. Eur Respir J. 2016;48:833-42.

50. Allaix ME, Fisichella PM, Noth I, Herbella FA, Borraez Segura B, Patti MG. Idiopathic pulmonary fibrosis and gastroesophageal reflux. Implications for treatment. J Gastrointest Surg. 2014;18:100-5.

51. Kahrilas PJ, Smith JA, Dicpinigaitis PV. A Causal Relationship Between Cough and Gastroesophageal Reflux Disease (GERD) has been Established: A Pro/Con Debate. Lung. 2014;192:39-46.

52. Del Grande LM, Herbella FA, Bigatao AM, Jardim JR, Patti MG. Inhaled Beta Agonist Bronchodilator Does Not Affect Transdiaphragmatic Pressure Gradient but Decreases Lower Esophageal Sphincter Retention Pressure in Patients with Chronic Obstructive Pulmonary Disease (COPD) and Gastroesophageal Reflux Disease (GERD). Am Surg. 2016;20:1679-82.

53. Kempainen RR, Savik K, Whelan TP, Dunitz JM, Herrington CS, Billings JL. High prevalence of proximal and distal gastroesophageal reflux disease in advanced COPD. Chest. 2007;131:1666-71.

54. Patti MG, Tedesco P, Golden J, Hays S, Hoopes C, Meneghetti A, Damani T, Way LW. Idiopathic pulmonary fibrosis: how often is it really idiopathic? J Gastrointest Surg. 2005;9:1053-6.

55. Tosato F, Marano S, Mattachione S, Luongo B, Paltrinieri G, Mingarelli V, Vasapollo L. Surgical treatment of gastroesophageal reflux disease. Advances in endoscopic surgery. 2011; p.259-90. Prof. Cornel Iancu (Ed.), ISBN: 978953-307-717-8, InTech, Available from: http://www.intechopen.com/books/ advances-in-endoscopic-surgery/surgical-treatment-of-gastroesophagealreflux-disease.

56. Wileman SM, McCann S, Grant AM, Krukowski ZH, Bruce J. Medical versus surgical management for gastro-oesophageal reflux disease (GORD) in adults. Cochrane Database Syst Rev. 2010;17(3):CD003243.

57. Bello B, Herbella FA, Allaix ME, Patti MG. Impact of minimally invasive surgery on the treatment of benign esophageal disorders. World J Gastroenterol. 2012;18:6764-70.

58. Herbella FA, Tedesco P, Nipomnick I, Fisichella PM, Patti MG. Effect of partial and total laparoscopic fundoplication on esophageal body motility. Surg Endosc. 2007;21:285-8.

59. Ireland AC, Holloway RH, Toouli J, Dent J. Mechanisms underlying the antireflux action of fundoplication. Gut. 1993;34:303-8.

60. Scheffer RC, Tatum RP, Shi G, Akkermans LM, Joehl RJ, Kahrilas PJ. Reduced tLESR elicitation in response to gastric distension in fundoplication patients. Am J Physiol Gastrointest Liver Physiol. 2003;284:G815-20.

61. Ness-Jensen E, Lindam A, Lagergren J, Hveem K. Weight loss and reduction in gastroesophageal reflux. A prospective population-based cohort study: the HUNT study. Am J Gastroenterol. 2013;108:376-82.

62. Mathus-Vliegen LM, Tytgat GN. Twenty-four-hour $\mathrm{pH}$ measurements in morbid obesity: effects of massive overweight, weight loss and gastric distension. Eur J Gastroenterol Hepatol. 1996;8:635-40.

63. Mathus-Vliegen EM, van Weeren M, van Eerten PV. LOS function and obesity: the impact of untreated obesity, weight loss, and chronic gastric balloon distension. Digestion. 2003;68:161-8.

64. Telem DA, Altieri M, Gracia G, Pryor AD. Perioperative outcome of esophageal fundoplication for gastroesophageal reflux disease in obese and morbidly obese patients. Am J Surg. 2014;208:163-8.

65. Campos GM, Peters JH, DeMeester TR, Oberg S, Crookes PF, Tan S, et al. Multivariate analysis of factors predicting outcome after laparoscopic Nissen fundoplication. J Gastrointest Surg. 1999;3:292-300.

66. Luketina RR, Koch OO, Köhler G, Antoniou SA, Emmanuel K, Pointner R. Obesity does not affect the outcome of laparoscopic antireflux surgery. Surg Endosc. 2015;29:1327-33.

67. Chisholm JA, Jamieson GG, Lally CJ, Devitt PG, Game PA, Watson DI. The effect of obesity on the outcome of laparoscopic antireflux surgery. J Gastrointest Surg. 2009;13:1064-70.
68. Morgenthal CB, Lin E, Shane MD, Hunter JG, Smith CD. Who will fail laparoscopic Nissen fundoplication? Preoperative prediction of long-term outcomes. Surg Endosc. 2007;21:1978-84.

69. Wang YR, Dempsey DT, Richter JE. Trends and perioperative outcomes of inpatient antireflux surgery in the United States, 1993-2006. Dis Esophagus. 2011;24:215-23.

70. Pagé MP, Kastenmeier A, Goldblatt M, Frelich M, Bosler M, Wallace J, Gould J. Medically refractory gastroesophageal reflux disease in the obese: what is the best surgical approach? Surg Endosc. 2014;28:1500-4.

71. Varela JE, Hinojosa MW, Nguyen NT. Laparoscopic fundoplication compared with laparoscopic gastric bypass in morbidly obese patients with gastroesophageal reflux disease. Surg Obes Relat Dis. 2009;5:139-43.

72. Daes J, Jimenez ME, Said N, Daza JC, Dennis R. Laparoscopic sleeve gastrectomy: symptoms of gastroesophageal reflux can be reduced by changes in surgical technique. Obes Surg. 2012;22:1874-9.

73. Melissas J, Leventi A, Klinaki I, Perisinakis K, Koukouraki S, de Bree E, Karkavitsas N. Alterations of global gastrointestinal motility after sleeve gastrectomy: a prospective study. Ann Surg. 2013;258:976-82.

74. Tolonen P, Victorzon M, Niemi R, Mäkelä J. Does gastric banding for morbid obesity reduce or increase gastroesophageal reflux? Obes Surg. 2006;16:1469-74.

75. Ovrebø KK, Hatlebakk JG, Viste A, Bassøe HH, Svanes K. Gastroesophageal reflux in morbidly obese patients treated with gastric banding or vertical banded gastroplasty. Ann Surg. 1998;228:51-8.

76. Rebecchi F, Rocchietto S, Giaccone C, Talha A, Morino M. Gastroesophageal reflux disease and esophageal motility in morbidly obese patients submitted to laparoscopic adjustable silicone gastric banding or laparoscopic vertical banded gastroplasty. Surg Endosc. 2011;25:795-803

77. Tai CM, Huang CK, Lee YC, Chang CY, Lee CT, Lin JT. Increase in gastroesophageal reflux disease symptoms and erosive esophagitis 1 year after laparoscopic sleeve gastrectomy among obese adults. Surg Endosc. 2013;27:1260-6.

78. Sheppard CE, Sadowski DC, de Gara CJ, Karmali S, Birch DW. Rates of reflux before and after laparoscopic sleeve gastrectomy for severe obesity. Obes Surg. 2015;25:763-8.

79. Ortega J, Escudero MD, Mora F, Sala C, Flor B, Martinez-Valls J, et al. Outcome of esophageal function and 24-hour esophageal $\mathrm{pH}$ monitoring after vertical banded gastroplasty and Roux-en-Y gastric bypass. Obes Surg. 2004;14:1086-94.

80. Schauer PR, Ikramuddin S, Gourash W, Ramanathan R, Luketich J. Outcomes after laparoscopic Roux-en-Y gastric bypass for morbid obesity. Ann Surg. 2000;232:515-29.

81. Madalosso CA, Gurski RR, Callegari-Jacques SM, Navarini D, Mazzini G, Pereira Mda S. The Impact of Gastric Bypass on Gastroesophageal Reflux Disease in Morbidly Obese Patients. Ann Surg. 2016;263:110-6.

82. Frezza EE, Ikramuddin S, Gourash W, Rakitt T, Kingston A, Luketich J, Schauer P. Symptomatic improvement in gastroesophageal reflux disease (GERD) following laparoscopic Roux-en-Y gastric bypass. Surg Endosc. 2002;16:10.

83. Valezi AC, Herbella FA, Junior JM, de Almeida Menezes M. Esophageal motility after laparoscopic Roux-en-Y gastric bypass: the manometry should be preoperative examination routine? Obes Surg. 2012;22:1050-4.

84. Wang G, Agenor K, Pizot J, Kotler DP, Harel Y, Van Der Schueren BJ, et al. Accelerated gastric emptying but no carbohydrate malabsorption 1 year after gastric bypass surgery (GBP). Obes Surg. 2012;22:1263-7.

85. Allaix ME, Fisichella PM, Noth I, Mendez BM, Patti MG. The pulmonary side of reflux disease: from heartburn to lung fibrosis. J Gastrointest Surg. 2013; 17:1526-35

86. Hurst JR, Vestbo J, Anzueto A, Locantore N, Müllerova H, Tal-Singer R, et al. Susceptibility to exacerbation in chronic obstructive pulmonary disease. New Engl J Med. 2010;363:1128-38.

87. Sontag SJ, O'Connell S, Khandelwal S, Greenlee H, Schnell T, Nemchausky $\mathrm{B}$, et al. Asthmatics with gastroesophageal reflux: long term results of a randomized trial of medical and surgical antireflux therapies. Am J Gastroenterol. 2003;98:987-99.

88. Perrin-Fayolle M, Gormand F, Braillon G, Lombard-Platet R, Vignal J, Azzar $\mathrm{D}$, et al. Long-term results of surgical treatment for gastroesophageal reflux in asthmatic patients. Chest. 1989;96:40-5.

89. Eryuksel E, Dogan M, Olgun S, Kocak I, Celikel T. Incidence and treatment results of laryngopharyngeal reflux in chronic obstructive pulmonary disease. Eur Arch Otorhinolaryngol. 2009;266:1267-71.

90. Sweet MP, Patti MG, Hoopes C, Hays SR, Golden JA. Gastro-oesophageal reflux and aspiration in patients with advanced lung disease. Thorax. 2009;64:167-73.

91. Hartwig MG, Anderson DJ, Onaitis MW, Reddy S, Snyder LD, Lin SS, Davis RD. Fundoplication after lung transplantation prevents the allograft dysfunction associated with reflux. Ann Thorac Surg. 2011;92:462-8.

(cc) $\mathrm{BY}-\mathrm{NC}$ 